\title{
Conscientious objection: reflections for nursing in Portugal
}

\author{
Objeção de consciência: reflexões para a enfermagem em Portugal \\ Objeción de conciencia: reflexiones para la enfermería en Portugal
}

\section{Sandra Paço ${ }^{a}$ \\ Sérgio Deodato}

\section{ABSTRACT}

Objective: to discuss conscientious objection in nursing, identifying the ethic and legal basis for this decision-making.

Methodology: qualitative study in which the methodology used was ethical reflection based on a legal analysis of the laws in question, proceeding to a bibliographical and documentary research

Conclusions: Portuguese law and ethical pillars that form the basis of the Code of Ethics of nurses in Portugal defend the freedom of conscience as a professional practice. However, the obligation to protect human life, which imposes the need for coordination between this protection and the exercise of the right to conscientious objection on the part of the nurse, is also clear.

Keywords: Ethics in nursing. Nursing legislation. Beginning of human life.

\section{RESUMO}

Objetivo: Proceder a uma discussão acerca da objeção de consciência na prática da enfermagem de forma a identificar a fundamentação ética e legal, para esta tomada de decisão.

Metodologia: Estudo qualitativo no qual a metodologia utilizada foi a reflexão ética com base numa análise jurídica das leis em apreço, procedendo-se a uma pesquisa bibliográfica e documental.

Conclusão: A lei portuguesa e as bases éticas que constituem a base do Código Deontológico dos enfermeiros em Portugal, protegem a liberdade de consciência como um direito profissional. Todavia, é também clara a obrigação de proteção da vida humana, pelo que se impõe a necessidade de articulação entre esta proteção e o exercício do direito à objeção de consciência por parte do enfermeiro. Palavras-chave: Ética em enfermagem. Legislação de enfermagem. Início da vida humana.

\section{RESUMEN}

Objetivo: llevar a cabo un debate sobre la objeción de conciencia, en la práctica de enfermería, con el fin de identificar la base ética y jurídica de esta toma de decisiones.

Metodología: estudio cualitativo en el que la metodología fue la reflexión ética basada en un análisis jurídico de las leyes en cuestión, procediendo la búsqueda bibliográfica y documental

Conclusión: la ley portuguesa y bases éticas que forman la base de nuestro Código de Ética, protegen la libertad de conciencia, que es un valor fundamental para las sociedades democráticas y plurales. Sin embargo, también es obligación clara protección de la vida humana desde su forma más cruda (desde el comienzo de la vida humana), por lo que impone la necesidad de coordinación entre esta protección y la existencia de aborto legal en la legislación nacional.

Palabras clave: Ética en enfermería. Legislación de enfermería. Comienzo de la vida humana.
D0I: $\quad$ http://dx.doi.org/10.1590/1983-

1447.2015.04.53242 


\section{口INTRODUCTION}

This article addresses the issue of conscientious objection related to the professional act of nurses, particularly in regard to care decision at the beginning of life. The beginning of life is usually defined in ethical terms as the period of human development including pregnancy planning, pregnancy itself and birth. Because it is a period of people's lives which involves many decisions that have ethical consequences, various ethical issues that relate to nursing care are identified in the literature, the main fields and family planning, medically assisted procreation and abortion from which emerge ethical problems that health professionals in general and nurses in particular are faced with.

In care decisions related to ethical problems identified in their clinical practice, the nurses are faced with a conflict between their values and their ethical principles and those of the people in their care. This is what happens in care decisions regarding the beginning of life.

Being confronted with a request for care - in an abortion, for example - the nurse can decide not to accept the practice of this act, if it is considered as being in violating of their professional value of respect for life. With this confrontation, nurses can make use of their right to conscientious objection, with the decision consisting in their will to not perform a certain action, because it goes against the values of this professional, we can say that this is a conflict between the individual conscience and care request.

During this reflection, focus will be made primarily on the issue of abortion, because this is one of the major ethical problems related to the beginning of life, with which nurses are confronted. It should be noted, however, that the concept of conscientious objection is much broader. In all the ethical problems in health, we can also make use of conscientious objection in other situations where there is conflict between the care that we are asked for and our values and ethical principles ${ }^{(1)}$.

Thus, this article uses the reflection on conscientious objection in nursing related to the ethical issues concerning the beginning of life as its methodology, based on a legal analysis of the main laws regulating conscientious objection in Portugal and an ethical analysis of the Portuguese professional conduct regulations on this subject. The intention is to deepen ethical reflection on this theme, but with a proper legal and ethical support.

\section{The regulatory framework of conscientious objection in Portuguese nursing}

In Portugal, the liberalization of abortion until the 10th week of pregnancy gave rise to a huge debate in society, with the emergence of questions regarding the issue of conscientious objection, in particular for abortions performed upon request of woman, without the need for any other reason. The legalization of abortion has fostered a discussion of the conflict between the freedom of the woman in this decision and freedom of health professionals involved. It is mandatory therefore, that some thought on the determination of the nurse's role in this decision be made, as a health care professional, since nursing has the role of performing care throughout man's life cycle ${ }^{(2)}$.

We always remember that freedom of conscience is a fundamental human right (as we shall see in legislation mentioned later on) and that this right is also enshrined by the Order of Nurses in Portugal, in its Code of Ethics (Decree-Law N. 104/98 of April 21 / Statute of Nurses), for these professionals. Thus, the nursing professional is a conscientious objector when, for reasons of philosophy, ethics, morals or religion he "is convinced that it is legitimate to not obey a particular order, considering that it threatens life, goes against the dignity of the individual or against the code of ethics"(2). We can also say that conscientious objection is a "subjective position, protected constitutionally, which translates into a failure to comply with obligations and not practicing legally foreseen acts because the individual's own convictions on the subject prevent him from performing them, and these acts and defaults are exempt from any sanctions"(2).

Conscientious objection in nursing care also means a decision to not do a particular act and therefore "always implies a refusal of care and therefore a violation of the right to care by the other person" (3). Thus, it is necessary to exercise some reflection about this conflict and above all, understand how this right is founded.

The research that supported this article began in the international legal sources, so the first look focuses on the "Universal Declaration of Human Rights"(4). This Declaration aims to be "a common standard of achievement for all peoples and all nations", and states in its Article 18 that "Everyone has the right to freedom of thought, conscience and religion; this right includes freedom to change his religion or belief, and freedom to manifest his religion or belief, alone or in community with others and in public or private, in teaching, practice, worship and observance". The right to freedom of thought, on which is based the right to conscientious objection is whereby consecrated.

The "European Convention on Human Rights"(5) also states, in its Article 9 paragraph 1 that "Everyone has the right to freedom of thought, conscience and religion .... It also states in number 2 of this same Article, that existing constraints on the exercise of this freedom will be "those that, prescribed by law are necessary in a democratic society, to 
public safety, protection of order, public health or morals, or protection of the rights and freedoms of others".

The Portuguese legislation ensures the right to conscientious objection of citizens and health professionals, equally. The analysis begins with the "Constitution of the Republic" (6) that, in its Article 41, explicitly establishes the right to conscientious objection for all citizens, as a right related to freedom of conscience.

Being the Portuguese Constitution the basis of all Portuguese law, it is clear that conscientious objection is a right of any Portuguese citizen (including health professionals, and particularly nurses)

One of the first legal references to conscientious objection in health, was made only in 1984, with Law 3/84, of March 24, concerning sex education and family planning, which establishes the guarantee of the right to conscientious objection for health professionals. It is stated in Article 11 that "doctors are assured the right to conscientious objection when asked to practice artificial_ insemination or voluntary sterilization".

The Penal Code, in its successive revisions, also included the right to conscientious objection for these professionals in cases of abortion requests (Law 6/84 of May 11; Decree Law 48/95 of March 15; Law 90 / 97 of July 30 and Law $16 / 2007$ of April 17). These successive changes in law, related to voluntary pregnancy interruption, occurred towards further liberalization, with the extension of deadlines, and also by precluding wrongfulness of the expectants own will until the tenth week (in the latest review).

Law 6/84, of May $11^{(7)}$ is the first concerning the exclusion of some types of unlawful abortion. To date, any type of abortion was a punishable crime. Exclusion situations are considered under this law, namely those involving a risk to life or health of the woman, cases where_incurable disease, serious disease or malformation of the unborn child is foreseen, or in cases of rape.

This law, the right to conscientious objection and the form of its manifestation are ensured (Article 4, subitem 2 states that "Conscientious objection is expressed in a document signed by the objector and its decision shall be communicated to the pregnant woman or whoever can give consent in her consent, under Article 141 of the Penal Code').

Still within the scope of the beginning of life, in 2006, the right to objection in the Law on Medically Assisted Procreation is mentioned once again ${ }^{(8)}$. This bill is referred to because it has the particularity of showing the need for the objector to explain the reason for that decision, establishing in paragraph 3 of its Article 11 that "a professional's refusal to specify, reasons of clinical order or other reasons on which conscientious objection, specifically, is based" (and in that sense it is singular, because no other laws make reference to this obligation). The explanation of the objection, stated in law, constitutes a form of reflection about our values and ethical conscience that should guide our care, which is an appeal to the reasons for the decision and seems quite appropriate and necessary.

In 2007, the illegality exclusion law in cases of voluntary pregnancy termination (IVG) is changed once again with the Law 16 / 2007, of April $17^{\left({ }^{9}\right)}$, that predicted conscientious objection for professionals of health from its onset. This law is again extending deadlines and permits abortion in woman who are up to ten weeks pregnant, through own decision. The law also establishes the requirement of the abortion act be performed in establishments that are officially approved. It is regulated that _ objectors may not participate in the planned consultations, prior to the act of IVG, or the follow-up of pregnant women during this period of reflection (provided for by law, and which must be of at least 3 days).

This law also mentions that conscientious objection should be expressed "in a document signed by the objector, which is to be presented, where appropriate, to the clinical director or the director of nursing of all health facilities where the objector performs services for, and where voluntary interruptions of pregnancy are performed" (number 4 of Article 6). In practice, conscientious objection is expressed in a document signed by the objector, which must be submitted, as appropriate, to the clinical director or the director of nursing of all health facilities where the objector provides service, and where voluntary interruptions of pregnancy are performed, with the existence of a document where the name of the professional, the number of their professional certificate, date and signature should be. The document should also specify which subitems of Article 142, n. 1 of the Penal Code the objection refers to. It is also in this document that the professional undertakes to assist women whose health is compromised or at risk resulting from the voluntary interruption of pregnancy. They also agree to refer these women to the relevant departments within the legal deadlines. Thus, the right to professional conscientious objection does not prevail over the right to receive health care. If there is a decision by nurses not to act, there is a duty to refer the person concerned to another professional who is able - and not a conscientious objector - to carry out the intervention.

On the other hand, once conscientious objection is invoked, it necessarily _ produces effects regardless of the nature of health facilities where the objector provides service, and the need for consistency is evident, for the professional who declares himself an objector in public service, will also 
be an objector in a private institution. If it incurs in absence, ethical and legal sanction will apply.

It exists because in Portugal there is a right to abortion in certain circumstances which are prescribed by law, but it confers the right to objection by professionals. This ensures the protection of health professionals, where they are able to not perform acts that violate their conscience, whenever they are provided by law, as in the case of abortion.

Some authors ${ }^{(10)}$ argue that according to the "Abortion Act" of 1967 (1st Law in England to allow legal abortion within certain criteria), no one is required to participate in any treatment therein, except as necessary to prevent serious health damage or death of the pregnant woman. This obligation is also shaped in the Portuguese legislation. For this reason, many authors invoke the principle of double effect, in order to make the loss of freedom of conscience in detriment of values such as life and health of others acceptable.

Like most laws indicates, the objection can only exist in relation to a concrete act. Professionals directly linked to the act itself, as the doctor, anesthetist or nurse, can only invoke the limit for the refusal of the procedure. However, the essential care, such as post-anesthetic cannot be declined.

Based on these different opinions, the nurses can rely on the right to freedom of conscience. Ethically, this right is granted in the form of conscientious objection, after being regulated in more detail in "Regulation of the Right to Exercise Conscienscious Objection" of the Board of Nurses ${ }^{(2)}$. The right to objection, by these professionals, "is based on the right to refuse a legal obligation on behalf of individual conscience" (11) and, when the nursing action to be developed is an order issued by their superiors or by a prescription held within their interdependent and independent operations, putting into question the values and the principles of a professional or is at odds with the religious convictions, moral or ethics of nursing, and before which a refusal to its achievement based on reasons of conscience is manifested (11).

The Code of Ethics of Portuguese nurses, states in its Article 78 (Law No. 111/2009 of September 16) that interventions in nursing "are performed with the concern of the defense of freedom and human and nurse dignity". Analyzing this Article, it can be said that the defense of freedom implies acceptance of the choices of others, respecting the integrity and professional awareness of the professional himself. Interventions in nursing have ever-present concerns about the values of freedom and human dignity of the person, but obviously respects the same values for the nurse. For this reason, in subitem b) of the Board Statute, Article 75 paragraph 2, states that the nurse has the right to "respect for their political, religious, ideological and philosophical" views and the right to conscientious objection.

Article 76 states that it is the duty of nurses to "practice the profession with the appropriate scientific and technical knowledge, with respect for life, human dignity and the health and well-being of the population". Article 82 provides that "the nurse, in respect of the equal right life throughout the life cycle, assumes the obligation to attribute to the life of any person equal value, protecting and defending human life under all circumstances".

Respect for life is undoubtedly one of the values governing this profession, although life cycle is yet to be defined in this Article 82, so that we can determine when to initiate this protection. The criteria adopted by the Board of Portuguese Nurses is not clear, leaving the definition of the beginning of human life open. In a brief summary, we remember the existence of different judgments about this concept: Design; nesting; appearance of the primitive streak; onset of brain activity or viability ${ }^{(12)}$.

In 2005, however, the Board publishes the "Code of Ethics of Nurses: from comments to Case Analysis"(13) where it is possible to determine what is meant by Life Cycle and consequently the beginning of human life. It begins with fertilization, according to the authors, and ends with death. But, the assessment made by the agent (in this case by the nurse) and its ethical reflection, always remains in relation to the option of conscientious objection, which will be based on their personal and professional values.

According to the Board of Nurses, the "moral conscience must be respected because it is the most specific dimension of human dignity" (13). The legitimacy of the objections come from the reflection that took place about their own personal values, and to which they intended to remain true, so it is recommended that this be an act of good faith and respect for the freedom of thought of others.

\section{- CONCLUSION}

We tried to combine current Portuguese health legislation on the issue of conscientious objection in this article, especially as it relates to the professional practice of nursing, enabling the identification of the ethical and legal basis for this decision-making. This analysis emerges as being clearly protective of freedom of conscience in Portugal, as well as equal rights for nurses in particular.

The defense of life is a moral, ethical and deontological obligation for this professional group and, conscientious objection grants this ethical experience under the current legislation. Above all, it allows nurses an experience with their profession, which guarantees the existence of 
congruence between the acts that they practice and the concomitant affirmation of personal values, but without prejudice to the right to care held by the client (and therefore the obligation to forward to another professional). The law also requires the organization of services in the sense that there is no damage to the client, also forcing the professional to be held accountable to their statement, so that this organization is possible. Lastly, we do not doubt the need for this right to be reconsidered whenever there is danger to the health or life of the client.

As was shown, whether in the main international legislative documents, or in the laws that are part of the Portuguese legal system, the right to conscientious objection is clearly established. Through it, the nurse can resolve ethical conflicts between any occasional requests for care and their moral values and principles.

\section{REFERENCES}

1. Paço S. Breve reflexão sobre a objeção de consciência. Salutis Scientia. 2013;5: 40-50.

2. Ministério da Saúde (PT). Decreto-lei no 104/98, de 21 de abril. Cria a Ordem dos Enfermeiros e aprova o respectivo estatuto. Diário da República. 1998 abr. 21;(93 I Série A):1739-57. Aterado pela Lei 111/ 2009 de 16 de setembro.

3. Deodato S. Responsabilidade profissional em enfermagem: valoração da sociedade. Coimbra: Almedina; 2008.
4. Declaração Universal dos Direitos do Homem: adotada e proclamada pela Resolução n. 217 A (III) da Assembléia Geral das Nações Unidas, em10 de dezembro de 1948 [cited 2015 jul. 30]. Available at: http://direitoshumanos.gddc.pt/3_1/ IIIPAG3_1_3.htm

5. Conselho da Europa (FR). Convenção Europeia dos Direitos Humanos [Internet]. Strasbourg: Tribunal Europeu dos Direitos do Homem, 2003 [cited 2015 jul. 10. Available at: http://www.echr.coe.int/Documents/Convention_POR.pdf

6. Presidência da República (PT). Decreto da aprovaçãa da Constituição de 10 de abril. Diário da República. 1976 abr. 10; (86 I Série):738-75.

7. Assembleia da República (PT). Lei 6/84, de 11 de maio. Exclusão da ilicitude em alguns casos de interrupção voluntária da gravidez. Diário da República. 1984 maio 11;(109| Série):1518-9.

8. Assembleia da República (PT). Lei no 32/2006, de 26 de julho. Procriação medicamente assistida. Diário da República. 2006 jul. 26(143 I Série):5245-50.

9. Assembleia da República (PT). Lei n016/2007, de 17 de abril. Exclusão da llicitude nos casos de interrupção voluntária da gravidez. Diário da República. 2007 abr. 17;(75 1a Série):2417-8.

10. Mason JK, Laurie GT. Law and medical ethics.7th ed. Oxford: Oxford University Press; 2006.

11. Nunes L. Breve memória cronológica da objecção de consciência. Revista da Ordem dos Enfermeiros. 2007:26(6):19-21.

12. Loureiro I C . Estatuto do embrião. In: Archer L, Biscaia, Osswald W, Renaud M. Novos desafios à bioética. Lisboa: Porto Editora; 2001. p. 110-21.

13. Nunes L, Amaral M, Gonçalves R. Código deontológico do enfermeiro: dos comentários à análise de casos. Lisboa: Edição da Ordem dos Enfermeiros; 2005.

\section{Author's address:}

Sandra Paço

Rua D. Jorge da Costa, 12 $2^{\mathrm{A}}, 13^{\mathrm{a}} \mathrm{dto}$

1400-143 Lisboa, Portugal

E-mail: sandrapac@hotmail.com
Received: 03.02.2015

Approved: 19.08.2015 